The research program of the Center for Economic Studies (CES) produces a wide range of theoretical and empirical economic analyses that serve to improve the statistical programs of the U.S. Bureau of the Census. Many of these analyses take the form of CES research papers. The papers are intended to make the results of CES research available to economists and other interested parties in order to encourage discussion and obtain suggestions for revision before publication. The papers are unofficial and have not undergone the review accorded official Census Bureau publications. The opinions and conclusions expressed in the papers are those of the authors and do not necessarily represent those of the U.S. Bureau of the Census. Republication in whole or part must be cleared with the authors.

\title{
INTERNATIONAL TRADE AND THE CHANGING DEMAND FOR SKILLED WORKERS IN HIGH-TECH MANUFACTURING
}

\author{
by
}

Julie A. Silva *

University of Florida

CES 07-22 August, 2007

All papers are screened to ensure that they do not disclose confidential information. Persons who wish to obtain a copy of the paper, submit comments about the paper, or obtain general information about the series should contact sang V. Nguyen, Editor, Discussion Papers, Center for Economic Studies, Bureau of the Census, 4600 Silver Hill Road, 2K132F, Washington, DC 20233, (301-763-1882) or INTERNET address sang.v.nguyen@census.gov. 


\begin{abstract}
This paper examines the effects of changing trade pressures on the demand for skilled workers in high-tech and traditional manufacturing industry groupings and in individual high-tech sectors. For industry groupings, changing import and export prices have mixed effects, with coefficients switching signs between wage share and employment share models. These findings suggest that changes in earnings and employment of skilled workers are not moving in the same direction in response to shifting trade pressures. For individual high-tech sectors, both price and orientation measures had significant effects, but the direction of these effects varied substantially by sector.

* The material is based upon work supported by the Cooperative State Research, Education, and Extension Service, U.S. Department of Agriculture, under Agreement No. 00-35401-9204. Any opinions, findings, conclusions, or recommendations that are expressed in this article are those of the author and do not necessarily reflect the views of the U.S. Department of Agriculture. The research in this paper was conducted while the authors were Special Sworn Status researchers of the U.S. Census Bureau at the Center for Economic Studies. Research results and conclusions expressed are those of the authors and do not necessarily reflect the views of the Census Bureau. This paper has been screened to insure that no confidential data are revealed. I thank Robin Leichenko and Mike Lahr for all their help with this research. I also thank Mark Brown and Stewart Duncan for their extensive comments on earlier drafts of this paper. Any errors or omissions are the sole responsibility of the author.
\end{abstract}




\section{Introduction}

Growing wage inequality within the United States and other post-industrial countries has been widely documented in the social science literatures (Levy and Murnane 1992; Harrison 1994; Gottschalk and Smeeding 1997; Acemoglu 2002; Rodríguez-Pose and Gill 2006; Silva and Leichenko 2004). There is a general consensus that one important driver of rising inequality has been the rising wage premium for skilled workers. The growing wage gap between skilled and unskilled workers coincides with several other economic trends, including accelerated involvement in international trade, growth in skill-biased technological change, and increasing foreign competition facing high-tech manufacturing industries. Thus, there has been heightened interest in examining the effects of international trade on income inequality.

This study extends the work of Bernard and Jenson (1995, 1997, 1999), Silva and Leichenko (2004) and others who investigate the relationship between international trade and income inequality. Trade-based explanations of rising inequality commonly focus on factors that erode the position of unskilled U.S workers, such as the impact of international competition with low-wage countries (Wood 1994; Rodrik 1997). The relationship between international trade and wage inequality is usually analyzed within a Heckscher-Ohlin (HO) framework, which predicts that liberalized trade will lead developed countries such as the United States to specialize in the production of skillintensive goods where they have a comparative advantage. The HO model also suggests that trade can increase income inequality within advanced economies by increasing the demand and wages for skilled workers relative to unskilled workers. In particular, the Stolper-Samuelson theorem suggests that free trade lowers the real wage of scarce factors 
of production. Since the United States has a relative abundance of skilled labor, trade with developing countries - where low-skilled labor is abundant - is predicted to lower both demand and wages for unskilled workers (Wood 1994). ${ }^{1}$

Leichenko and Silva (2004) note that the regional impacts of international trade on manufacturing employment and earnings are complex and are not always consistent with the predictions of HO theory and conventional wisdom. However, international trade has been linked to deindustrialization in traditional manufacturing sectors, a development that is seen as a key driver of the growing wage gap between high-skill and low-skill workers within the U.S. (Cline 1997, 2001; Leichenko and Coulsen 1999; Wood 1994). Berman et al. (1998), Lawrence and Slaughter (1993), and others note a shift towards higher skill intensity within U.S. manufacturing. The decline of traditional manufacturing has coincided with the rise of so-called high-technology industries in the U.S. (Markusen et al. 1986; Glasmeier 1991).

Various criteria are used to define high-tech industries, including the research and development expenditures as a percentage of sales, technical sophistication of products, and degree of human capital employed (Erikson et al. 1995; Markusen et al. 1986). Classic examples of high-tech sectors include the semiconductor, medical devices, and aircraft industries. High-tech sectors are commonly believed to employ high shares of skilled labor and exhibit a high degree of innovation in designing new products and production processes. Other notable characteristics of high-tech manufacturing include longstanding linkages with the U.S. Department of Defense and distinctive patterns of spatial agglomeration (Glasmeier 1991). Despite the number of defining characteristics

\footnotetext{
${ }^{1}$ Wood $(1994,1998)$ also attributes skill-biased technological change to trade-based defensive innovations in response to competitive pressures from low-wage countries.
} 
associated with high-tech manufacturing, empirical work suggests that a high degree of variation, in terms of growth, competition, and geographical concentration exists among high-tech industries (Markusen et al. 1986).

The research-intensive orientation of high-tech sectors relative to traditional manufacturing has implications for economic development. In high-tech sectors the competitive advantage rests on research and development expenditures, not on low-skill, low-wage labor. This accounts, in part, for why high-tech sectors enjoy substantial government support. Moreover, in many cases high-tech manufacturing is seen as the last bastion of high paying but low-skilled production jobs. Policymakers and scholars have argued that there is a direct relationship between maintaining high-tech manufacturing and the nation's long term economic well-being (PCAST 2003). Thus there has been considerable debate over how to preserve the competitiveness of U.S. high-tech industries. At the subnational level, regions and localities compete to attract and maintain high-tech industrial development.

However, Addison et al. (2002) find that workers employed in manufacturing industries with high shares of R\&D personnel have increased rates of trade-induced job loss. In addition, Bardhan and Howe (2001) find that blue-collar manufacturing workers are more vulnerable to foreign outsourcing in California—a region with a high concentration of high-tech manufacturing — than in the rest of the U.S. And Kuehn and Braschler (1986) find that trade-induced employment losses vary by manufacturing industry and Census region. Yet little investigation has been done as whether the hightech sectors react differently to international trade pressures than traditional manufacturing sectors, and if these reactions vary by region. An investigation of this 
relationship is especially pertinent given that high-tech industries are heavily represented in U.S. exporting sectors and thus especially likely to be affected by trade pressures (Leichenko and Coulson 1999).

This study investigates the impact of international trade on the demand for skilled labor relative to unskilled labor across traditional and high-technology manufacturing sectors across U.S. counties. Carlino et al. (1990) and Cronovich and Gazel (1998) find that the impacts of exchange rate movements vary in the U.S. at the state-level. Moreover, Krugman (1991) and Shelburne and Bednarzik (1993) find that manufacturing sectors involved in trade tend to be more spatially concentrated than other, non-traded sectors. By using sector and country-level data, this analysis includes over 300,000 observations and takes into account regional differences in the effects of international trade on changing skill premia across U.S. counties. Thus this study contributes to our understanding of how workers in different locations fared with regards to changing trade pressures over the 1972-1997 time period.

The key objectives of this paper are three-fold: (1) to determine the effects of changing exchange rates and trade orientation on the relative demand for skilled manufacturing workers in the United States, (2) to examine if high-tech industries respond differently to changing trade pressures than traditional manufacturing sectors, and (3) to identify relationships between shifting trade pressures and changing labor demand across individual high-tech sectors. Since trade-related pressures vary from industry to industry, sector-specific analyses are necessary to better our understanding of the relationship between trade and inequality (Wood 1998). 
The remainder of the article is organized as follows. Section 2 explores the trends in employment, earnings, and skill-intensity for both high-tech and traditional manufacturing sectors between 1972 and 1997 for the United States at the two-digit and four-digit SIC levels. Section 3 presents the theoretical and methodological framework for this study. Using regression analysis, Section 4 measures the effect of international trade pressures on the demand for skilled labor for high-tech and traditional manufacturing industry groupings. The regression model is also estimated independently for all high-tech sectors at the four-digit SIC level. Section 5 concludes this paper by highlighting key findings from this study and directions for future research.

\section{Patterns of Employment, Earnings, and Skill-intensity in U.S. Manufacturing}

Before examining changes in U.S. manufacturing at the four-digit SIC level, this paper briefly investigates patterns in manufacturing employment, earnings, and total value of industry shipments across two-digit industrial sectors using time-series data obtained from REIS (U.S. Bureau of the Census 2001). The two-digit sectors which contain high technology products include chemicals (SIC 28), fabricated metals (SIC 34), industrial machinery (SIC 35), electronics (SIC 36), transportation equipment (SIC 37), instruments (SIC 38) and miscellaneous manufacturing industries (SIC 39).

Table 1 presents evidence that high-tech manufacturing grew over the 1972-1997 time period of the study while traditional manufacturing experienced employment declines. As illustrated in Table 1, total employment for the six two-digit sectors containing high-tech products increased by $4 \%$. In contrast, total employment for traditional manufacturing sectors declined by $8 \%$. Sectors with high-tech products also had higher growth in real manufacturing earnings per worker (24\%) than did traditional 
manufacturing (20\%). Differential growth between high-tech and traditional manufacturing sectors was most evident with regards to increases in the value of total shipments. At the two-digit sector level, the combined growth in shipment value of hightech sectors (86\%) was more than double that of traditional manufacturing sectors (41\%).

Examination of Table 1 reveals that high-tech employment and earnings growth was driven by gains in instruments and related products (SIC 38). Instruments had large percentage gains in employment, earnings, and output value. Except for instruments, employment growth in high-tech sectors was under $10 \%$ and several of these sectors witnessed an overall decline in employment. Since contributions to aggregate growth also depend on employment weight, industrial machinery and equipment (SIC 35) is likely to have also made a large contribution to high-tech employment growth. ${ }^{2}$ Industrial machinery and equipment employed more than twice as many people as instruments and related products over the time period of the study (US Census, all years). In terms of wage gains, instruments and chemicals showed the greatest gains with $46 \%$ and $35 \%$, respectively. Real earnings per worker increased across all sectors, but the magnitude of the change varied widely. A traditional sector, tobacco manufactures (SIC 21), showed the largest gain with real average wages increasing by $89 \% .{ }^{3}$ Growth in total value of industry shipments was positive for most traditional sectors and all high-tech sectors. For traditional manufacturing sectors, rubber and miscellaneous plastic products (SIC 30) fared the best, with 129\% growth, and leather and leather products (SIC 31) experienced the greatest decline, shrinking by $46 \%$. Electronics (SIC 36) showed the most rapid growth among high-tech sectors, with a 129\% increase in value of shipments.

\footnotetext{
${ }^{2}$ Thanks to Mark Brown for pointing out this important fact.

${ }^{3}$ The majority of this growth occurred in the cigar production subsector (SIC 212) in the early 1990s.
} 
Figure 1 illustrates the patterns of traditional and manufacturing earnings by twodigit sectors across US counties in 1972. The maps show that, in general, traditional manufacturing earnings were greater, and more spatially dispersed, across the US than high-tech manufacturing earnings. High-tech manufacturing earnings in 1972 appear higher in West coast and East coast counties with a smattering of high earning counties distributed throughout the country. Interestingly, the counties with the highest earnings for traditional manufacturing also have higher earnings for high-tech manufacturing relative to other counties. This suggests linkages between traditional and high-tech manufacturing earnings at the county level. One possible explanation for these linkages could be higher levels of unionization or relative supply of skilled labor in certain counties.

Table 2 illustrates changes in earnings, employment, and share of production (i.e., unskilled) workers for a sample of 33 four-digit high-tech industrial sectors over the study period. ${ }^{4}$ For all sectors, total employment increased by $7 \%$ and real earnings per production worker increased by 19\%. The figures presented in Table 2 suggest that production workers have lost ground in high-tech manufacturing sectors. The employment share for production workers decreased from 65\% in 1972 to 58\% in 1997. Wage patterns tell a similar story, with production worker wage share declining from $55 \%$ in 1972 to $44 \%$ in 1997.

Examination of Table 2 reveals dramatic differences across the sectors in manufacturing employment patterns. Medicinal chemicals and botanical products (SIC 2833) had the largest employment increase, followed by electric components (SIC 3679)

\footnotetext{
${ }^{4}$ This sample of 33 four-digit sectors was selected, in part, because sufficient firm data existed at the county-level for these sectors to allow for an analysis that would not breech the confidentiality requirement of the Center for Economic Studies.
} 
and surgical and medical instruments (SIC 3841). All three sectors registered employment gains in excess of $200 \%$. However, total employment declined for many other high-tech sectors over the 1972-1997 time period, with household audio and video equipment (SIC 3651) showing the greatest loss with declines of 65\%. Real earnings per production worker also varied across sectors. All sectors besides small arms (SIC 3484), office machines (SIC 3579), and electronic computers (SIC 3571) experienced positive growth in real earnings per production worker. The largest gains were made by production workers in electric machinery (SIC 3699), where real production worker earnings increased by $45 \%$.

Demand for lower-skilled workers, as measured by production worker employment and wage shares, declined over the study period for the majority of sectors. This pattern provides further evidence that unskilled labor has lost ground in high-tech manufacturing over the study period. In general, production worker employment and wage shares decreased by $10 \%$ or less between 1972 and 1997. A notable exception was telephone and telegraph apparatus (SIC 3661) where production worker employment and wage shares decreased by $28 \%$ and $33 \%$, respectively. Not surprisingly, production worker wage shares were lower than production worker employment shares in all years, and for all sectors. This most likely reflects the lower wages paid to low-skilled production workers relative to higher-skilled non-production workers.

Figure 2 illustrates the patterns of percentage change in earnings for traditional and manufacturing by two-digit sectors across US counties between 1972 and 1997. The maps show little evidence of widespread clustering across counties. This is true for both traditional and high-tech manufacturing, suggesting that—in terms of gains in earnings- 
no specific geographic regions in the country conferred particular advantages to either type of manufacturing workers. One exception is California, where high tech earnings appear to have increased at a higher rate than earnings from traditional manufacturing sectors. The opposite scenario seems to be true in the case of the inland west.

The following regression analysis enables an exploration of the significance of international trade pressures in accounting for these observed changes in high-tech manufacturing while controlling for other factors.

\section{Modeling Approach}

This study uses panel regression analysis to capture the effects of international trade and other variables on the demand for skilled labor across industrial sectors at the county-level. The county- and sector-level manufacturing data were calculated using several sources. National-level data on U.S. exchange rates, U.S. industrial exports by country of destination, and U.S. industrial imports by county of origination was combined with county-level data on manufacturing shipments and shares of industrial production by four-digit sector. The national export and import data were taken from databases developed by Robert Feenstra $(1996,1997)$. The exchange rate data were obtained from the International Financial Statistics database (IMF 2002). State and county data were obtained from the Longitudinal Research Database (LRD) of the U.S.

Census. The LRD contains data on total shipments, total employment, capital output, and other variables for manufacturing firms included in the U.S. Annual Survey of Manufacturers and the U.S. Census of Manufactures for the period between 1972 and 1997. This analysis uses a panel dataset covering six years: 1972, 1977, 1982, 1987, 
1992, and 1997. The data is aggregated from firm-level establishments at the four-digit SIC industry level for each U.S. county. ${ }^{5}$

Studies of the wage gap in the U.S. have frequently investigated the possible effects of trade on shifts in demand for high skilled labor relative to lower skilled workers (Bernard and Jensen 2000; Feenstra and Hanson 1999, 1996; Sachs and Shatz 1994; Borjas and Ramey 1995; Wood 1994). The model used in this study expands on these earlier studies by including agglomeration measures and broader indicators of international trade. Using four-digit SIC industry data by county, the relative demand for skilled labor is modeled as a function of industry characteristics, urbanization levels, manufacturing levels, unionization levels, and exchange rate and trade orientation measures.

Following Feenstra and Hanson (1999, 1996), Haskel and Slaughter (1998), Berman et al. (1994) and others, a measure of capital intensity is included to control for differences in industry asset structures. Agglomeration measures are included to control for possible effects of regional concentrations of urban and industrial activity on skill premiums. Previous studies find that U.S. urban areas have a higher skilled work force than nonmetropolitan areas (Wheeler 2005; Glickman 1998). Therefore a population density measure was included in the model. A measure of unionization is included in the model as prior research has found that deunionization is strongly correlated with increasing income inequality (Bernard and Jensen 2000; Gottschalk and Smeeding 1997; Kodras 1997). In keeping with other wage inequality studies, two industry size control measures are included in the model: total value of shipments and total employment. Since

\footnotetext{
${ }^{5}$ For a more detailed discussion of the construction of the industry- and county-level trade database, see Leichenko and Silva (2004) and Silva and Leichenko (2004).
} 
shipments and employment are included, the model allows for an examination of the effects of productivity on wage levels. In this sense, the study examines whether wage share of skilled workers is higher in cases where shipments are higher, after controlling for employment.

Finally, the trade variables allow for an exploration of the effects of trade pressures on the relative demand for skilled workers. The inclusion of international trade indicators is similar to the work of Bernard and Jensen (2000), Silva and Leichenko (2004), and Leichenko and Silva (2004). Both exchange rate and trade orientation measures are included to provide a gauge of external trade pressures at the four-digit industry level for the period from 1972 through 1997.

The basic form of the non-production wage share model may be represented as: Non-production wage share $=$ fn(international trade exchange rates, international trade orientation, capital intensity, industry size controls, agglomeration measures, unionization rates)

The dependent variable, non-production wage share, is the log of the average non-production workers' share of the industry wage bill for each four-digit SIC industry by county. Following Feenstra and Hanson (1999, 1996), Berman et al. (1994) and others, non-production wage share is used as a measure of the relative demand for skilled labor. Non-production and production worker status categories found in industry accounts are widely used as proxies for skilled and unskilled workers, respectively (Borjas et al. 1992; Lawrence and Slaughter 1993; Leamer 1993; Berman et al. 1994; Sachs and Shatz 1994; Haskell and Slaughter 2002; Yan 2005). However, using production and non-production status as proxies for skill levels has received criticism in 
the literature for being an unreliable measure of skill classification (Forbes 2001).

However, other scholars have argued that, despite problems with the non-

production/production classification, it provides clear results. For example, Berman et al.

(1994) and Slaughter (1998) note that studies using this measure tend to obtain similar

results to studies using other measures of skill such as educational attainment.

The measures of industry-level involvement in international trade include two

price-based measures, export exchange rate and import exchange rate, and two structural measures, export orientation and import orientation. These variables all measure industry trade pressures at the four-digit SIC level. On the basis of the methodology presented in Bernard and Jensen (2000), Leichenko and Silva (2004) and Silva and Leichenko (2004), these measures were constructed in the following fashion. For the price-based measures, national export and import exchange rates are first constructed for each four-digit manufacturing industry as the weighted sum of real exchange rate indices (U.S. dollar/foreign currency) across countries. The export exchange rate of each industry at the county-level is calculated by weighting each industry's national export exchange rate by each county's employment share in the industry during that year. ${ }^{6}$ The import exchange rate is weighted in the same manner. Both export and import exchange rate measures were averaged across sets of five years, in order to provide a more robust measure of standard trade patterns. As described in Leichenko and Silva (2004), exchange rates are proxies for the prices of exports within an industry and the prices of imports competing with goods produced by that industry.

\footnotetext{
${ }^{6}$ The exchange rates are nominal exchange rates deflated by GDP deflators in foreign currency per U.S. dollar, normalized to be 100 in 1993 . The year 1993 was selected as the base year because GDP data were the most complete for countries in the data set in that year.
} 
The structural measures are constructed in a similar fashion to the exchange rate measures. The national export orientation of each four-digit SIC industry is calculated as the value of export shipments divided by the total value of shipments in that industry. The export orientation of each industry at the country-level is then calculated as the weighted sum of industry export orientation, with the weights given by the county employment share in the four-digit SIC industry. The calculation of imports is similar to that of exports. The national import orientation of each four-digit SIC industry is calculated as the total value of import shipments divided by the total value of the shipments in that industry that are available in the U.S. (i.e., U.S. shipments plus imported shipments minus export shipments). Import orientation of each industry at the country-level is then calculated by weighting the national import orientation of the industry by the county's employment share in that industry. These structural measures are intended as estimates of the degree to which a four-digit SIC industry is internationally oriented.

Concerning the expected signs of trade variables, export exchange rate and export orientation are both expected to have a positive effect on the demand for skilled labor. Higher exchange rates (i.e., U.S. dollar depreciation) causes U.S. exports to become relatively cheaper, and it is expected that cheaper exports would result in more export shipments. Bernard and Jensen $(1997,1995)$ and Breau and Rigby (2006) find that exporting industries are more skill intensive than non-exporting industries. Therefore, increased participation in exports, either through changes in export exchange rates or increases in industry export orientation, is predicted to increase the relative demand for skilled labor. 
The expected relationship between import exchange rates and relative demand for skilled labor is negative. Decreased import competition that is due to higher import exchange rates (i.e., a weaker U.S. dollar) would be expected to benefit lower skilled workers who compete with international low-wage labor (Kletzer 2001; Revenga 1992). Therefore, higher prices for imported goods are expected to decrease the demand for skilled workers relative to unskilled workers.

Finally, the expected sign of import orientation is positive. A high value on the import orientation measure implies that the industry faces a high degree of competition from imports. As a result of these international competitive pressures, highly-import oriented industries are expected to be more likely to adopt labor saving technologies or outsource aspects of production that require low-skilled labor (Wood 1998; Feenstra and Hanson 1996, 1999). Therefore higher import orientation is expected to raise demand for skilled workers relative to unskilled labor.

Theory and previous empirical results suggest certain relationships between the other explanatory variables and returns to skill. Higher capital intensity of an industry is predicted to increase the industry's demand for skilled labor via the introduction of new technology which requires workers whose skills complement that technology (Haskel and Slaughter 1998; Berman et al. 1994; Wood 1994). Therefore, a positive relationship is expected between the measure of capital intensity and non-production wage share.

Concerning agglomeration, two measures, population density and manufacturing shares of employment are included. Population density is an indicator of the level of urbanization in a county. Because urban areas typically possess more educated populations than non-metropolitan areas, population density is expected to have positive 
effects on non-production wage share (Wheeler 2005). Regarding manufacturing shares of employment, research has found that the decline in U.S. manufacturing has led to higher inequality by lowering the demand for low-skilled workers relative to skilled workers (Karoly and Klerman 1994). Therefore the relationship between manufacturing employment share and relative demand for skilled labor is expected to be negative: higher shares of manufacturing should be associated with lower relative demand for skilled workers across industries.

In order to capture the effects of deunionization, unionization rates are included as a measure of unionization levels in a state. ${ }^{7}$ Since unionized jobs tend to offer higher returns to low-skilled labor, they narrow the wage gap between differences in skills. Therefore, unionization rates are expected to have a negative effect on the relative wage share for skilled labor.

A basic control for industry size, total employment, is included in the model. Bernard and Jensen $(1997,1995)$ find that larger firms have a higher employment share of non-production workers. Assuming total employment is positively associated with the presence of larger firms, total employment is expected to have a positive effect on the demand for skilled labor. Following Bernard and Jensen (1997), the variable total value of shipments is included to capture industry demand shifts. Bernard and Jensen (1997), Feenstra and Hanson (1999, 1996), and Berman et al. (1994) all find a positive correlation between the demand for an industry's products and the industry's use of skilled labor. As a result, a positive relationship is expected between total value of shipments and relative demand for skilled labor.

The non-production employment share model takes a similar form:

\footnotetext{
${ }^{7}$ State unionization rates were uses because county-level unionization data were not available.
} 
Non-production employment share $=$ fn(international trade exchange rates, international trade orientation, capital intensity, industry size controls, agglomeration measures, unionization rates)

The dependent variable in the employment model, non-production employment share, is the log of the average non-production workers' employment share for each fourdigit SIC industry by county. The explanatory variables are identical to those used in the wage model. The expected signs on the explanatory and trade variables are also the same.

In order to investigate the differential effects of trade pressures on skill premiums across industry types, the wage and employment models were first estimated across all high-tech sectors and all traditional manufacturing industries. These industry groupings were selected in order to investigate if high-tech sectors respond differently to changes in exchange rates and trade orientation than traditional manufacturing sectors. High technology sectors were classified according to the detailed list of advanced technology sectors compiled at the four-digit SIC level by Erickson et al. (1995). ${ }^{8}$ Next, the models were estimated separately for each four-digit SIC high-tech sector. These regressions allow examination of variation responses to shifting trade pressures across individual high-tech industries.

In all cases, the models are estimated as industry- and county-level panels by the ordinary least-squares method in first differences. ${ }^{9}$ The use of first differences controls for the effects of industry- and county-invariant differences. As a result, the models analyze the change in non-production worker demand (relative to production workers) as

\footnotetext{
${ }^{8}$ Complete definitions for each of these advanced technology categories are also provided in Abbott, et al. (1989).

${ }^{9}$ All models were also estimated via fixed effects. The results from the models using fixed effects were similar to those of the first difference models and are available from the author upon request.
} 
a function of the changes in trade pressures. Before the models were estimated, bivariate correlations were calculated to investigate possible collinearity between the explanatory variables. These statistics revealed little evidence of collinearity.

One limitation of the modeling approach is that the analysis is limited to the direct effects of international trade pressures on labor demand within industries. The analysis looks at how exchange rates and trade orientation of each four-digit SIC industry directly affects non-production workers' relative wage and employment shares in that industry. This allows for the measurement of external trade pressures on individual manufacturing industries by county, but it does not address the input-output linkages between industries such as the effects trade pressures on one industry in one county may have on other industries in other counties.

\section{Empirical Results}

\section{Regression Results}

High Tech and Traditional Manufacturing Industry Groupings

Table 3 presents the regression results for the wage and employment share models across the high-tech and traditional manufacturing industry groupings. For both models, the signs on the variable coefficients—-when significant—are consistent across industry groupings. These findings suggest that international trade pressures and other factors have similar impacts on labor demand across all manufacturing sectors. Stated differently, there is little evidence that high-tech sectors respond differently to changing international trade pressures than traditional manufacturing sectors across counties. However, the directions of the effects were not always consistent with theoretical predictions. 
Concerning the control variables, the signs on capital intensity run counter to initial expectations. When significant, capital intensity has a consistently negative effect on demand for skilled workers across both industry groupings. This negative relationship is present in both the wage and the employment share models. This result indicates that industries with increasing levels of capital investment per worker have decreasing demand (as measured by both employment and wage levels) for skilled workers. While these results contrast with our initial expectations, they comport with the findings of Bernard and Jensen (1997) who suggest that changes in skilled employment and wage share are linked to demand variables such as foreign sales, rather than technology or investment.

The signs for total value of shipments and total employment are mixed. Total value of shipments has the expected positive effect on relative demand for skilled labor in the wage model. But the opposite effect is present in the employment models. Since total value of shipments captures demand shifts, these findings suggest increased product demand has positive effects on the wage share of skilled workers, but that changes in employment shares do not keep pace. One possible explanation for this finding is greater increases in the wages of skilled labor relative to employment could be the result of higher worker productivity. Stated differently, increases in worker productivity might lead to fewer jobs for skilled workers, but higher wages for those who are employed.

In contrast, the total employment variable has the expected positive result on the demand for skilled labor in the employment models, but a negative effect in the wage models. These findings suggest that growing industries employ more skilled workers but pay them less. One possible explanation for this finding is that, as employment grows, 
average wages do not keep up. An increasing supply of skilled workers could contribute towards a downward pressure on wages even as employment opportunities in certain industries are increasing.

The state unionization variable has the expected negative effect on relative demand for skilled workers in the wage models. However, the opposite effect is present in the employment models. These findings suggest that increasing rates of unionization actually increase demand for skilled workers in terms of employment but decrease demand as measured by wage shares. One possible explanation for this effect is that unions resist downward pressure on unskilled worker wages more effectively than they protect unskilled employment. In addition, labor-intensive industries may be more inclined to leave unionized areas leading to declining unskilled labor employment shares (Glickman 1998).

With regard to the agglomeration measures, both manufacturing employment share and population density have the expected signs on significant coefficients. Manufacturing share has the expected negative effect on demand for skilled workers in terms of employment share and wage share. These findings support the deindustrialization hypothesis that declines in manufacturing have led to lower demand for unskilled workers (Gottschalk and Smeeding 1997). Population density has the expected positive effect on demand for skilled workers in terms of employment share and wage share, suggesting that urban areas are home to industries requiring more skilled labor. These finding are consistent with work by Wheeler (2005) who finds that returns to skill and wage inequality are particularly pronounced in U.S. metropolitan areas. 
Turning to the trade variables, the results are consistent across both industry groupings. The effects of exchange rates on the demand for skilled labor are somewhat mixed. The export exchange rate variables, which represent proxies for the prices of an industry's international export goods, are negative for the wage share models but positive for the employment share models. The negative and significant coefficient on the export exchange variable in the wage model suggests that higher prices for export goods produced by an industry are associated with lower wage shares for skilled workers. These negative effects contrast with initial expectations that increases in demand for exports would result in greater demand for skilled labor. However, the positive effects of export exchange rates in the employment share model do conform to initial expectations and suggest that increased competitiveness of U.S. exports is associated with increases in demand for skilled workers. Taken together, the mixed effects of export exchange rates suggest that wages for skilled workers are not keeping pace with non-production employment growth. One possible explanation for this is that an increasing supply of skilled and highly educated workers in the U.S. labor market is leading to more competition for skilled employment and putting downward pressure on wages of skilled manufacturing workers in certain sectors.

Concerning import exchange rates, the parameter coefficients generally have the expected negative effect. The negative and significant coefficient on the import exchange rate variable suggests that increasing prices for the imported goods with which an industry competes results in increasing demand for low-skill labor. In the wage share model for the high-tech sector grouping, however, import exchange rates have a positive effect on demand for skilled labor. Generally, a weaker dollar (i.e., more expensive 
imports) is believed to benefit low-skill, labor-intensive industries. Yet most high-tech products are producer goods, so they are inputs into traditional production (Cohen and Zysman 1987). Therefore greater competitiveness of traditional manufacturing industries could also stimulate demand for high-tech products that require a higher degree of skilled labor.

With regards to import orientation, the effects were consistent with initial expectations. The import orientation variable has a positive and significant coefficient in both the wage and employment models. This positive relationship is consistent with the prediction that industries facing increasing import competition will employ less low-skill labor. This suggests that unskilled workers lose more ground in industries with higher international competition. Export orientation's effects are often insignificant, but there is some evidence that increasing degrees of export orientation increases demand (as measured by wage shares) for skilled workers in traditional manufacturing sectors. The positive effects of export orientation are consistent with the theory that industries respond to greater international competition with defensive innovation and skill-biased technological change which leads to the displacement of less skilled workers (Wood 1998). This finding is also consistent with the work of Bernard and Jensen (1997) who find that export-oriented industries employ more skilled workers.

\section{Individual High-Tech Sector Regressions}

Tables 4 and 5 report the regression results from the non-production worker demand models across 18 four-digit high-technology manufacturing industries. ${ }^{10}$ The

\footnotetext{
${ }^{10}$ Due to space constraints, regression results are only reported for a sample of the sectors. Regression output for other high-tech sectors is available from the author upon request.
} 
results for the sector-specific models show a great deal of variation across high-tech manufacturing sectors, both for the control and the trade variables. This finding is consistent with other research that finds high-tech sectors to be very dissimilar with regards to patterns of employment and growth (Markusen et al. 1986; Glasmeier 1991). ${ }^{11}$

Concerning the control variables, the coefficients are often insignificant in both the wage share and employment share models. When the coefficients on the control variables are significant, they generally have the expected signs. For example, the industry size control variable, total employment, consistently has the expected positive effect in the employment share models. These results indicate that increases in total industry employment are associated with increasing demand for skilled workers. This evidence suggests that growing high-tech industries are increasing the share of skilled workers employed.

Turning to the trade variables, there is more significance among the coefficients but the effects are mixed. The wage and employment models have similar rates of significance, but the findings of the wage model are more in line with theoretical predictions. This suggests that changes in trade pressures consistently have an impact on the relative demand for skilled labor in high-tech manufacturing industries, but that the effects often run counter to initial expectations.

Trade theory predicts that higher exchange rates (i.e., a weaker dollar) will result in more export shipments and thus increase the relative demand for skilled labor. For imports, a higher exchange rate is predicted to increase prices for imported goods (i.e., decrease import competition) and increase in the demand for low-skilled labor. However,

\footnotetext{
${ }^{11}$ Rigby and Essletzbichler (2002) also find that the effect of agglomeration economies across industries at the 4-digit level were highly variable.
} 
for several sectors, the opposite relationships hold true. For example, phonographic records and prerecorded audio tapes and disks (SIC 3652) and pharmaceutical preparations (SIC 2834) have negative signs on export exchange rates and positive signs on import exchange rates. The direction of these relationships is consistent for both the wage and employment share models. These findings suggest that decreases in the prices of U.S. exports (i.e., more competitive exports) lead to decreasing demand for skilled labor in these sectors, while increasing prices of imports (i.e., less import competition) leads to higher demand for skilled workers.

The counter-intuitive relationship between changing international trade pressures and these two sectors (SIC 3652 and SIC 2834) may be explained, in part, due to the structure of these industries. For both of these sectors, a few main companies dominate the industry. In the case of phonograph records (SIC 3652), five companies-BMG, EMI, Sony, UGM, and Warner Music Group—accounted for approximately 75\% of the world market share in 1998 (Hutchinson et al. 2006). Somewhat similarly, the top 40 companies accounted for $64 \%$ of global sales in pharmaceutical preparations (SIC 2834) in 1998 (Chemical Market Reporter 1999). Both industries are also highly reliant on research and development and sales promotion activities. The high levels of industry concentration and reliance on research and development make both sectors fit the profile of industries that Caves et al. (1993) describe as being susceptible to the inefficient use of nonproduction labor under certain conditions. According to Caves et al. (1993) the inefficient accumulation of non-production workers arises from the combined effects of lower levels of competition, uncertainty regarding the marginal productivity of nonproduction workers, and the natural drive of bureaucracies to increase in size. Thus 
greater competition from imports (or the need for greater efficiency that may accompany the entry into or expansion in export markets) could force firms to trim 'fat' from their non-production employment ranks. Thus the results in this analysis for the phonographic records and pharmaceutical industries provide some support for the findings of Caves et al. (1993).

Regarding the structural measures of trade, increasing degrees of export and import orientation are both predicted to increase the demand for skilled workers. Instead, the parameter coefficients on export orientation are consistently negative, signifying that increases in the international orientation of industries leads to declines in the relative demand for skilled workers. One possible explanation for this finding is that international competition prompts greater increases in skilled worker productivity—relative to unskilled worker productivity—which decreases the relative demand for skilled workers. Another possible explanation is that growing competition for export markets means that greater export orientation weakens high-tech industries and results in decreasing demand for skilled labor.

Six of the 18 sampled high-tech sectors generally have the predicted signs for the trade variables, especially with regards to the price-based measures. These sectors consist of construction machinery and equipment (SIC 3531), office machines (SIC 3579), household audio and video equipment (SIC 3651), semiconductors (SIC 3674), electric components (SIC 3679), and surgical and medical instruments (SIC 3841). However, these sectors share few unifying characteristics which could explain theory's successful predictions of trade-related effects on employment demand for these industries. For example, three sectors had negative employment change over the time period of the 
study, while the others had employment gains of over 100\%. Regarding earnings, the electric components sector experienced a 14\% decline in real earnings per production worker while average earnings of unskilled labor in the semiconductor sector increased by $42 \%$. Finally, production worker employment and wage shares decreased in all six sectors but by varying amounts.

A key question raised by the findings of this study is why so much variation exists across high-tech sectors with regards to labor demand responses to changing trade pressures. The different sector-specific effects of trade could be due to several factors. (1) Sectors could be experiencing different levels of foreign competition, thus making the trade pressures unique to each specific sector. (2) Product cycles for the goods produced by each sector may also vary, causing sectors to be more or less vulnerable to trade pressures at different time periods. This differential vulnerability may impact how labor demand shifts in response to changes in trade pressures. (3) Some sectors may be more prone to outsourcing when faced with competitive pressures than others. For example, sectors that contract with the U.S. Department of Defense may be less likely to outsource production for security reasons.

\section{Conclusions}

State and local governments put considerable effort into attracting and maintaining high-tech manufacturing industries in an attempt to promote regional economic growth. Since competitive advantage in high-tech sectors rests on R\&D expenditures, rather than low-wage labor, these industries are often seen as drivers of employment growth in the U.S. However concerns about trade-related effects on employment in these sectors have emerged as foreign competition in high-tech industries 
has intensified. At the same time, workers in the U.S. are becoming increasingly stratified by skill. This analysis explored the impacts of changing trade pressures on the relative demand for skilled workers in high-tech manufacturing industries.

Two key findings emerge from this analysis. First, changes in exchange rates and trade orientation have similar effects across high-tech and traditional manufacturing industry groupings. This suggests that workers in high-tech industries are not immune to the problems caused by increasing foreign competition that confront labor in more traditional sectors. Interestingly, the signs on parameter coefficients for the exchange rate variables switch between the wage and employment share models. This suggests that wages and employment are often not moving in the same direction. The scenario where wage shares of skilled workers increases in high-tech sectors but their employment shares decrease suggests a story of skill-biased technological change or increased worker productivity. This scenario also provides some support for the theory of Caves et al. (1993) that manufacturing firms accumulate inefficient levels of non-production workers - due to the combined effects of low levels of competition, the difficultly in measuring non-production worker productivity, and the tendency of bureaucracies to increase in size-which they must reduce as a sector encounters greater competition.

In addition, the upward pressure on wages may be due to the higher degrees of skill required for the remaining jobs. Indeed there is evidence that the skill level required of all workers is increasing in high-tech manufacturing (NYT 2006). Evidence from this analysis indicates that increasing import exchange rates prompt labor demand shifts that are consistent with the increasing wage but decreasing employment scenario for skilled workers. Increasing export exchange rates are associated with the opposite scenario-the 
wage shares of skilled workers increase while their employment shares decrease. This suggests that employment opportunities for skilled workers are increasing in response to decreasing export prices, but that real wages are not keeping pace with employment growth. One possible explanation for this scenario is that an oversupply of skilled workers is exerting downward pressure on wages. Another possibility is that workers are failing to gain—in terms of higher wages—-from their increased productivity.

Secondly, evidence from this analysis suggests that there is high degree of variation in the trade-related effects on labor demand across individual high-tech sectors, and the direction of trade-related effects often runs counter to theoretical predictions. Detailed case studies of high-tech manufacturing sectors have shown that production is a very complex process, often involving international trade in intermediate imported inputs and outsourcing of the low-skill elements of production (Angel 1994; Scott 1992). The increasing use and importance of intermediate inputs in U.S. manufacturing could mean that more expensive imports (i.e., weaker dollar) could hurt U.S. industries rather than help them (Silva and Leichenko 2004; WSJ 2003). Growing competition in export markets could also explain the counterintuitive effects of trade found in some sectors. More competition may lead to labor saving technology, higher worker productivity, and declining U.S. market share in high-tech industries—all of which could result in decreasing demand for skilled workers (Leichenko 2000).

Taken together, the findings of this study are not consistent with the predictions of HO theory, which suggest that international trade will lead to an increase in the relative demand for skilled workers. Many high-tech sectors actually experience decreasing demand —in the form of employment shares, wage shares, or both—for skilled labor in 
response to increasing trade. Moreover, the regression results from the high-tech and traditional manufacturing groupings as well as the individual sector regressions suggest that trade-related demand shifts for more skilled labor (as measured by employment shares) are not always accompanied by corresponding increases in the relative wage shares of skilled worker, and vice versa. The lack of consistent Stolper-Samuelson wage effects could be due to the fact that the theorem does not consider intermediate inputs. Given that U.S. manufacturing input purchases accounted for fell over 50\% of the value of total shipments during the time period of the study, the importance of intermediate inputs most likely play a role in how international trade affects relative wages (Slaughter 1998).

In terms of implications for policy, the findings of this study suggest that hightech industries do not necessarily provide greater security for low-skilled manufacturing workers. Indeed, the results of this paper indicate that the demand for skilled labor in high-tech sectors responds to changing trade pressures in much the same manner as traditional manufacturing sectors. Therefore, policies designed to recruit and protect high-tech industries as a means to help low-skilled labor could well be ineffective. In addition, national and regional policies designed to encouraging job creation and retention in high-tech manufacturing industries may not mitigate the rising wage gap between skilled and unskilled workers in the U.S. Despite the competitive advantage enjoyed by advanced economies such as the U.S. in R\&D of high-tech manufacturing, the findings of this analysis suggests that high-tech industries respond no differently from traditional manufacturing in response to changing international trade pressures. 
Therefore, production workers in high-tech industries are likely to be as vulnerable as other manufacturing workers to foreign competition.

Ultimately what this analysis may reveal is that high-tech—as an analytical category—does not enhance our understanding of trade-inequality linkages within the manufacturing sector. Despite sharing a focus on research and development, high-tech sectors have little in common with regards to employment, growth, skill-intensity, and responses to trade pressures. Future work seeking to determine how international trade contributes rising wage inequality would benefit from the use of more detailed industry categories based on a greater number of shared characteristics. Further work needs to be undertaken at the sector level to understand why some sectors respond differently to changes in trade pressures than others, and why trade theory often fails to predict the direction of these responses. 


\section{References}

Abbott, T., R. McGluckin, P. Herrick, and L. Norfolk. 1989. Measuring the trade balance in advanced technology products. Discussion Paper CES 89-1. Washington DC: U.S. Bureau of the Census, Center for Economic Studies.

Acemoglu, D. 2002. Technical Change, Inequality, and the Labor Market. Journal of Economic Literature 40(1): 7-72.

Addison, J. T., D. A. Fox, and C. J. Ruhm. 2000. Technology, Trade Sensitivity, and Labor Displacement. Southern Economic Journal 66(3): 682-699.

Angel, D. P. 1994. Restructuring for Innovation: The Remaking of the U.S. Semiconductor Industry. New York and London: The Guilford Press.

Bardhan, A. D., and D. K. Howe. 2001. Globalization and Restructuring during Downturns: A Case Study of California. Growth and Change 32 (2): 217-235.

Berman, E., J. Bound, and Z. Griliches. 1994. Changes in the demand for skilled labor within U.S. manufacturing: evidence from the Annual Survey of Manufacturers. Quarterly Journal of Economics 109(2): 367-398.

Berman, E., J. Bound, and S. Machin. 1998. Implications of skill-biased technological change: international evidence. Quarterly Journal of Economics 113(4): 12451279.

Bernard, A. and Jensen, J.B. 1995. Exporters, Jobs, and Wages in U.S. Manufacturing: 1976-87. Brookings Papers on Economic Activity: Microeconomics. Washington, D.C.: Brookings Institute, pp. 67-119. . 1997. Exporters, Skill-Upgrading, and the Wage Gap. Journal of International Economics 42(1): 3-31. . 1999. “Exceptional Exporter Performance: Cause, Effect, or Both?” Journal of International Economics: 47(1): 1-25.

. 2000. Understanding Increasing and Decreasing Wage Inequality. In The Impact of International Trade on Wages, ed. Robert Feenstra. Chicago: National Bureau of Economic Research and University of Chicago Press, 227-267.

Borjas, G. J., R. J. Freeman, and L. F. Katz. 1992. On the labor market effects of immigration and trade. In Immigration and the work force, eds. G. Borjas and R. Freeman, 213-244. Chicago: University of Chicago Press.

Borjas, G. J. and V. A. Ramsey. 1995. Foreign competition, market power, and wage inequality. Quarterly Journal of Economics 110(1995): 1075-1110.

Breau, S. and D. L. Rigby. 2006. Is there really an export wage premium? A case study of Los Angeles using matched employee-employer data. Discussion Paper CES 
06-06. Washington, D.C.: U. S. Department of Commerce, Center for Economic Studies.

Carlino, G., B. Cody, and R. Voith. 1990. Regional Impacts of Exchange Rate Movements. Regional Science Perspectives 1:39-53.

Caves, R. E., M. B. Krepps, M. J. White, and H. Farber. 1993. Fat: The Displacement of Nonproduction Workers from U.S. Manufacturing Industries. Brookings Papers on Economic Activitiy. Microeconomics 1993(2): 227-288.

Chemical Market Reporter. 1999. Shares in the World Pharmaceutical Markets in 1998. Reed Business Information, FR22.

Cline, W. 1997. Trade and Income Distribution. Washington, D.C.: Institute for International Economics. . 2001. Trade, Immigration, and Wage Distribution. In The Causes and Consequences of Increasing Inequality, ed. Finis Welch. Chicago: University of Chicago Press, 241-261.

Cohen, S., and J. Zysman. 1987. Manufacturing Matters: The Myth of the Post-Industrial Economy. London: Basic Books.

Cronovich, R., and R. Gazel. 1998. Do Exchange Rates and Foreign Incomes Matter for Exports at the State Level? Journal of Regional Science 38(4): 639-657.

Forbes, K. 2001. Skill classification does matter: estimating the relationship between trade flows and wage inequality. Journal of International Trade and Economic Development 10(2) : 175-209.

Erickson, R. A., S. W. Friedman, and S. X. Lowe. 1995. State Industrial Exports, Export Promotion Programs, and Exporter Targeting. Smeal College of Business Administration, The Pennsylvania State University, University Park, PA.

Feenstra, R. C. 1996. U.S. Imports, 1972-1994: Data and Concordances. National Bureau of Economic Research, Working Paper 5515. Cambridge, MA: NBER.

. 1997. U.S. Exports, 1972-1994, with State Exports and Other U.S. Data. National Bureau of Economic Research, Working Paper 5990. Cambridge, MA: NBER.

Feenstra, R. C. and G. H. Hanson. 1996. Globalization, Outsourcing, and Wage Inequality. AEA Papers and Proceedings 86(2): 240-245.

. 1999. The impact of outsourcing and high-technology capital on wages: estimates for the United States, 1979-1990. Quarterly Journal of Economics 38(4): 355-374. 
Glasmeier, A. K. 1991. The High-Tech Potential: Economic Development in Rural America. New Brunswick, NJ: Center for Urban Policy Research.

Glickman, N. J. 1998. Prosperity and Inequality Among America's Cities and Regions. Center for Urban Policy Research, Working Paper No. 146. New Brunswick: Rutgers University.

Gottschalk, P. and T. M. Smeeding. 1997. Cross-national Comparisons of Earnings and Income Inequality. Journal of Economic Literature 35(2): 633-687.

Harrison, B. 1994. Lean and Mean. New York and London: The Guilford Press.

Haskell, J. and M. Slaughter. 2002. Does the sector bias of skill-biased technological change explain changing skill premia? European Economic Review 46(10): 17571783.Working Paper No. 6565.

Hutchinson, T., A. Macy, and P. Allen. 2006. Record Label Marketing Oxford: Elsevier Focal Press.

Karoly, L. A., and J. A. Klerman. 1994. Using regional data to reexamine the contribution of demographic and sector changes to U.S. wage inequality. In The changing distribution of income in an open U.S. economy, ed. J. H. Bergstrand, T. F. Cosimano, J. W. Houck, and R. G. Sheehan, 183-216. Amsterdam: NorthHolland.

Kodras, J. E. 1997. The changing map of American poverty in an era of economic restructuring and political realignment. Economic Geography 73(1) :67-93.

Kletzer, L. G. 2001. Job Loss from Imports: Measuring the Costs. Washington, D.C.: Institute for International Economics.

Krugman, P. 1991. Geography and Trade. Cambridge, MA: MIT Press.

Kuehn, J. A. and C. Braschler. 1986. Technology and Foreign Trade Impacts on U.S. Manufacturing Employment 1975-1980. Growth and Change 17(4): 46-60.

Lawrence, R. and M. Slaughter. 1993. Trade and U.S. wages: great sucking sound or small hiccup? Brookings Papers on Economic Activity, Microeconomics. Washington DC: Brookings Institution

Leamer, E. 1993. Trade, wages, and revolving door ideas. National Bureau of Economic Research Working Paper No. 4716

Leichenko, R. 2000. Exports, Employment and Production: A Causal Assessment of U.S. States and Regions. Economic Geography 76(4): 303-325. 
Leichenko, R., and Coulson, N. E. 1999. Foreign industrial exports and state manufacturing performance. Growth and Change 30(4): 479-506.

Leichenko, R. and J. Silva. 2004. International Trade, Employment and Earnings: Evidence for US Rural Counties. Regional Studies 38(4): 355-374.

Levy, F. and R. Murnane. 1992. U.S. earnings levels and earnings inequality: a review of recent trends and proposed explanations. Journal of Economic Literature 30(September): 1333-1381.

Markusen, A., P. Hall, and A. Glasmeier. 1986. High-Tech America. Boston: Allen \& Unwin.

NYT (New York Times) 2006. New York bets on high-tech to aid upstate, 28, October, p. A1.

PCAST (Presidents Council of Advisors on Science and Technology). 2003. Report on Technology Transfer of Federally Funded R\&D. Available at: http://www.ostp.gov/PCAST/PCASTTechTransferReport.pdf

Revenga, A. L. 1992. Exporting Jobs? The Impact of Import Competition on Employment and Wages in U.S. Manufacturing. The Quarterly Journal of Economics 107(1): 255-284.

Rigby, D. and J. Essletzbichler. 2002. Agglomeration and Productivity Differences in US Cities. Journal of Economic Geography 2(4): 407-432.

Rodríguez-Pose, A. and N. Gill. 2006. How does trade effect regional disparities? World Development 34(7): 1201-1222.

Rodrik, D. 1997. Has Globalization Gone Too Far? Washington, D.C.: Institute for International Economics.

Sachs, J. and H. Schatz. 1994. Trade and jobs in U.S. manufacturing. Brookings Papers on Economic Activity. Washington DC: Brookings Institution, 1-84.

Scott, A. J. 1992. Low-wage workers in a high-technology manufacturing complex: The Southern Californian electronics assembly industry. Urban Studies 29(8): 12311246.

Shelburne, R. C., and Bednarzik, R. W. 1993. Geographic concentration of tradesensitive employment. Monthly Labor Review 116(6): 3-13.

Silva, J. A., and R. M. Leichenko. 2004. Regional Income Inequality and International Trade. Economic Geography 80(30):261-286. 
Slaughter, M. J. 1998. What are the results of product-price studies and what can we learn from their differences? National Bureau of Economic Research Working Paper No. 6951.

U.S. Census. 1978. Statistical Abstract of the United States 1978. Washington D.C.: U.S. Census Bureau. . 2000. Statistical Abstract of the United States 2000. Washington D.C.: U.S. Census Bureau. . 2001. Regional Economic Information System, 1969-1999. Washington, D.C.: Bureau of Economic Analysis, Regional Economic Measurement Division.

WSJ (Wall Street Journal). 2003. The Steel Tariff's Cost. February 23, 2003, p. A14.

Wheeler, C. H. 2005. Cities, Skills, and Inequality. Growth and Change 36(3): 329-353.

Wood, A. 1994. North-South Trade, Employment and Inequality: Changing Fortunes in a Skill-Driven World. Oxford: Clarendon Press. . 1998. Globalisation and the Rise in Labour Market Inequalities. The

Economic Journal 108(450): 1463-1482.

Yan, B. 2005. Demand for Skills in Canada: The Role of Foreign Outsourcing and Information-Communication Technology. Economic Analysis (EA) Research Paper Series. Ottawa: Statistics Canada. 
Table 1. Changes in employment, earnings, and total value of shipments across two-digit SIC manufacturing sectors

\begin{tabular}{|c|c|c|c|c|c|}
\hline & $\begin{array}{l}\text { SIC } \\
\text { Code }\end{array}$ & 1987 US SIC Description & $\begin{array}{c}\text { Manufacturing } \\
\text { employment \% } \\
\text { change, 1972- } \\
1997\end{array}$ & $\begin{array}{c}\text { Real } \\
\text { manufacturing } \\
\text { earnings/worker } \\
\% \text { change, 1972- } \\
1997\end{array}$ & $\begin{array}{l}\text { Real total value of } \\
\text { manufacturing } \\
\text { shipments \% } \\
\text { change, 1972-1997 }\end{array}$ \\
\hline Traditional & 20 & Food and Kindred Products & $-0.6 \%$ & $3.5 \%$ & $30 \%$ \\
\hline Manuf. & 21 & Tobacco Manufactures & $-48.2 \%$ & $89.0 \%$ & $88 \%$ \\
\hline \multirow[t]{13}{*}{ Sectors } & 22 & Textile Mill Products & $-41.0 \%$ & $18.3 \%$ & $-10 \%$ \\
\hline & 23 & Apparel and Other Textile Products & $-39.4 \%$ & $8.6 \%$ & $-11 \%$ \\
\hline & 24 & Lumber and Wood Products & $9.8 \%$ & $5.6 \%$ & $45 \%$ \\
\hline & 25 & Furniture and Fixtures & $13.5 \%$ & $13.1 \%$ & $71 \%$ \\
\hline & 26 & Paper and Allied Projects & $-1.8 \%$ & $25.6 \%$ & $75 \%$ \\
\hline & 27 & Printing and Publishing & $45.2 \%$ & $8.3 \%$ & $115 \%$ \\
\hline & 29 & Petroleum and Coal Products & $-24.4 \%$ & $35.8 \%$ & $104 \%$ \\
\hline & 30 & Rubber and Misc. Plastics Products & $64.3 \%$ & $9.2 \%$ & $129 \%$ \\
\hline & 31 & Leather and Leather Products & $-69.4 \%$ & $13.1 \%$ & $-46 \%$ \\
\hline & 32 & Stone, Clay, Glass, and Concrete Products & $-18.8 \%$ & $11.7 \%$ & $32 \%$ \\
\hline & 33 & Primary Metal Industries & $-39.4 \%$ & $12.1 \%$ & $-1 \%$ \\
\hline & 39 & Misc. Manufacturing Industries & $-11.6 \%$ & $15.8 \%$ & $29 \%$ \\
\hline & & Total & $-8 \%$ & $20 \%$ & $41 \%$ \\
\hline High & 28 & Chemicals and Allied Products & $-2.0 \%$ & $34.8 \%$ & $107 \%$ \\
\hline Technology & 34 & Fabricated Metal Products & $3.8 \%$ & $9.3 \%$ & $39 \%$ \\
\hline Manuf. & 35 & Industrial Machinery and Equipment & $8.2 \%$ & $14.5 \%$ & $91 \%$ \\
\hline \multirow[t]{5}{*}{ Sectors } & 36 & Electrical and Electronic Equipment & $-4.8 \%$ & $24.1 \%$ & $129 \%$ \\
\hline & 37 & Transportation Equipment & $-9.1 \%$ & $16.5 \%$ & $68 \%$ \\
\hline & 38 & Instruments and Related Products & $79.6 \%$ & $45.6 \%$ & $116 \%$ \\
\hline & & Total & $4 \%$ & $24 \%$ & $86 \%$ \\
\hline & Source: & $\begin{array}{l}\text { County Business Patterns, } 1986-2001 \\
\text { US Census Longitudinal Research Databas } \\
\text { US Census Statistical Abstracts, } 1978 \text { and }\end{array}$ & $72-1997$ & & \\
\hline
\end{tabular}


Table 2. Changes in employment, earnings, and production worker shares across four-digit SIC manufacturing sectors

\begin{tabular}{|c|c|c|c|c|c|c|c|}
\hline SIC Code & 1987 US SIC Description & 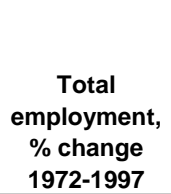 & $\begin{array}{c}\text { Real } \\
\text { earnings/ } \\
\text { production } \\
\text { worker, \% } \\
\text { change, 1972- } \\
1997\end{array}$ & $\begin{array}{c}\text { Production } \\
\text { worker } \\
\text { employment } \\
\text { share } 1972\end{array}$ & $\begin{array}{l}\text { Production } \\
\text { worker } \\
\text { employment } \\
\text { share } 1997\end{array}$ & $\begin{array}{c}\text { Production } \\
\text { worker wage } \\
\text { share } 1972\end{array}$ & $\begin{array}{c}\text { Production } \\
\text { worker wage } \\
\text { share } 1997\end{array}$ \\
\hline 2819 & Industrial Inorganic Chemicals, NEC & $-9 \%$ & $42 \%$ & $63 \%$ & $52 \%$ & $56 \%$ & $49 \%$ \\
\hline 2833 & Medicinal Chemicals and Botanical Products & $255 \%$ & $39 \%$ & $59 \%$ & $49 \%$ & $56 \%$ & $39 \%$ \\
\hline 2834 & Pharmaceutical Preparations & $-1 \%$ & $22 \%$ & $51 \%$ & $54 \%$ & $40 \%$ & $39 \%$ \\
\hline 3443 & Fabricated Plate Work (Boiler Shops) & $-7 \%$ & $0 \%$ & $73 \%$ & $73 \%$ & $66 \%$ & $62 \%$ \\
\hline 3484 & Small arms & $-39 \%$ & $-5 \%$ & $71 \%$ & $76 \%$ & $66 \%$ & $63 \%$ \\
\hline 3499 & Fabricated Metal Products, NEC & $31 \%$ & $9 \%$ & $76 \%$ & $74 \%$ & $66 \%$ & $63 \%$ \\
\hline 3519 & Internal Combustion Engines, NEC & $-18 \%$ & $9 \%$ & $75 \%$ & $73 \%$ & $69 \%$ & $64 \%$ \\
\hline 3531 & Construction Machinery and Equipment & $-36 \%$ & $3 \%$ & $73 \%$ & $67 \%$ & $68 \%$ & $59 \%$ \\
\hline 3541 & Machine Tools, Metal Cutting Types & $-45 \%$ & $16 \%$ & $64 \%$ & $58 \%$ & $57 \%$ & $49 \%$ \\
\hline 3542 & Machine Tools, Metal Forming Types & $-41 \%$ & $18 \%$ & $69 \%$ & $64 \%$ & $62 \%$ & $58 \%$ \\
\hline 3569 & General Industrial Machinery and Equipment, NEC & $86 \%$ & $13 \%$ & $65 \%$ & $60 \%$ & $54 \%$ & $46 \%$ \\
\hline 3571 & Electronic Computers & $38 \%$ & $-1 \%$ & $44 \%$ & $36 \%$ & $31 \%$ & $22 \%$ \\
\hline 3575 & Computer Terminals & $-41 \%$ & $8 \%$ & $55 \%$ & $49 \%$ & $49 \%$ & $35 \%$ \\
\hline 3579 & Office Machines, NEC & $-55 \%$ & $-14 \%$ & $60 \%$ & $51 \%$ & $49 \%$ & $38 \%$ \\
\hline 3651 & Household Audio and Video Equipment & $-65 \%$ & $6 \%$ & $81 \%$ & $68 \%$ & $70 \%$ & $50 \%$ \\
\hline \multirow[t]{2}{*}{3652} & Phonographic Records and Prerecorded Audio Tapes and & & & & & & \\
\hline & Disks & $-19 \%$ & $29 \%$ & $78 \%$ & $77 \%$ & $68 \%$ & $69 \%$ \\
\hline 3661 & Telephone and Telegraph Apparatus & $-18 \%$ & $29 \%$ & $70 \%$ & $42 \%$ & $62 \%$ & $29 \%$ \\
\hline 3671 & Electron Tubes & $-55 \%$ & $10 \%$ & $73 \%$ & $77 \%$ & $60 \%$ & $67 \%$ \\
\hline 3674 & Semiconductors and Related Devices & $104 \%$ & $42 \%$ & $60 \%$ & $53 \%$ & $44 \%$ & $35 \%$ \\
\hline 3679 & Electric Components, NEC & $252 \%$ & $10 \%$ & $65 \%$ & $63 \%$ & $47 \%$ & $44 \%$ \\
\hline 3699 & Electric Machinery, Equipment, and Supplies, NEC & $-5 \%$ & $45 \%$ & $61 \%$ & $61 \%$ & $43 \%$ & $44 \%$ \\
\hline 3721 & Aircraft & $-13 \%$ & $37 \%$ & $57 \%$ & $48 \%$ & $46 \%$ & $41 \%$ \\
\hline 3724 & Aircraft Engines and Engine Parts & $-19 \%$ & $24 \%$ & $58 \%$ & $58 \%$ & $48 \%$ & $46 \%$ \\
\hline 3728 & Aircraft Parts and Auxillary Equipment, NEC & $22 \%$ & $28 \%$ & $67 \%$ & $58 \%$ & $59 \%$ & $54 \%$ \\
\hline \multirow[t]{2}{*}{3822} & Automatic Controls for Regulating Residential and & & & & & & \\
\hline & Commercial Environments and Appliances & $-30 \%$ & $7 \%$ & $76 \%$ & $70 \%$ & $66 \%$ & $56 \%$ \\
\hline \multirow[t]{2}{*}{3823} & Industrial Instruments for Measurement, Display, and & & & & & & \\
\hline & Control of Process Variables; and Related Products & $35 \%$ & $12 \%$ & $52 \%$ & $44 \%$ & $43 \%$ & $32 \%$ \\
\hline 3824 & Totalizing Fluid Meters and Counting Devices & $95 \%$ & $44 \%$ & $67 \%$ & $69 \%$ & $56 \%$ & $61 \%$ \\
\hline \multirow[t]{2}{*}{3825} & Instruments for Measuring and Testing of Electricity and & & & & & & \\
\hline & Electrical Signals & $17 \%$ & $44 \%$ & $63 \%$ & $46 \%$ & $49 \%$ & $34 \%$ \\
\hline 3829 & Measuring and Controlling Devices, NEC & $14 \%$ & $5 \%$ & $52 \%$ & $53 \%$ & $47 \%$ & $39 \%$ \\
\hline 3841 & Surgical and Medical Instruments and Apparatus & $203 \%$ & $22 \%$ & $70 \%$ & $60 \%$ & $57 \%$ & $41 \%$ \\
\hline \multirow[t]{2}{*}{3842} & Orthopedic, Prosthetic, and Surgical Appliances and & & & & & & \\
\hline & Supplies & $110 \%$ & $10 \%$ & $68 \%$ & $62 \%$ & $54 \%$ & $42 \%$ \\
\hline 3861 & Photographic Equipment and Supplies & $-34 \%$ & $17 \%$ & $58 \%$ & $57 \%$ & $49 \%$ & $46 \%$ \\
\hline \multirow[t]{3}{*}{3944} & Games, Toys, and Children's Vehicles, Except Dolls and & & & & & & \\
\hline & Bicycles & $-53 \%$ & $8 \%$ & $79 \%$ & $73 \%$ & $64 \%$ & $55 \%$ \\
\hline & Total & $7 \%$ & $19 \%$ & $65 \%$ & $58 \%$ & $55 \%$ & $44 \%$ \\
\hline
\end{tabular}

Source: NBER-CES Manufacturing Industry Database, 1972-1997 
Table 3. Regression coefficients for wage share and employment share models for high-tech and traditional manufacturing industry groupings ( $t$-statistics in parentheses)

\begin{tabular}{|c|c|c|c|c|c|}
\hline \multirow[b]{2}{*}{ Explanatory } & \multirow{2}{*}{ Dependent } & \multicolumn{2}{|c|}{ Non-production Wage Share } & \multicolumn{2}{|c|}{ Non-production Employment Share } \\
\hline & & $\begin{array}{l}\text { High-Tech } \\
\text { Sectors }\end{array}$ & $\begin{array}{l}\text { Non-High-Tech } \\
\text { Sectors }\end{array}$ & $\begin{array}{l}\text { High-Tech } \\
\text { Sectors }\end{array}$ & $\begin{array}{l}\text { Non-High-Tech } \\
\text { Sectors }\end{array}$ \\
\hline Intercept & & $\begin{array}{l}0.0025^{\star \star} \\
(1.6)\end{array}$ & $\begin{array}{l}0.0043^{*} \\
(10.2)\end{array}$ & $\begin{array}{l}0.0022 \\
(1.3)\end{array}$ & $\begin{array}{l}0.0075^{\star} \\
(16.6)\end{array}$ \\
\hline Capital Intensity & & $\begin{array}{l}0.0004 \\
(0.5)\end{array}$ & $\begin{array}{l}-0.0022^{*} \\
(-9.6)\end{array}$ & $\begin{array}{l}-0.0023^{\star} \\
(-2.7)\end{array}$ & $\begin{array}{l}-0.0048^{\star} \\
(-19.9)\end{array}$ \\
\hline Population Density & & $\begin{array}{l}0.0230^{*} \\
(2.1)\end{array}$ & $\begin{array}{l}0.0007 \\
(0.2)\end{array}$ & $\begin{array}{l}0.0431^{*} \\
(3.5)\end{array}$ & $\begin{array}{l}0.0252^{*} \\
(6.9)\end{array}$ \\
\hline Manufacturing Share & & $\begin{array}{l}-0.280{ }^{*} \\
(-7.6)\end{array}$ & $\begin{array}{l}-0.0458^{\star} \\
(-4.6)\end{array}$ & $\begin{array}{l}-0.4215^{\star} \\
(-10.1)\end{array}$ & $\begin{array}{l}-0.1833^{*} \\
(-16.8)\end{array}$ \\
\hline State Unionization Rate & & $\begin{array}{l}-0.0004^{*} \\
(-2.7)\end{array}$ & $\begin{array}{l}-0.0001^{*} \\
(-3.2)\end{array}$ & $\begin{array}{l}0.0003^{\star \star} \\
(1.7)\end{array}$ & $\begin{array}{l}0.0002^{*} \\
(3.6)\end{array}$ \\
\hline Total Shipments & & $\begin{array}{l}0.0141^{*} \\
(8.6)\end{array}$ & $\begin{array}{l}0.0094^{*} \\
(18.2)\end{array}$ & $\begin{array}{l}0.0025 \\
(1.3)\end{array}$ & $\begin{array}{l}-0.0047^{*} \\
(-8.6)\end{array}$ \\
\hline Total Employment & & $\begin{array}{l}-0.0086^{*} \\
(-4.8)\end{array}$ & $\begin{array}{l}-0.0009 \\
(-1.5)\end{array}$ & $\begin{array}{l}0.0233^{*} \\
(11.5)\end{array}$ & $\begin{array}{l}0.0344^{\star} \\
(58.1)\end{array}$ \\
\hline Export Exchange Rates & & $\begin{array}{l}-0.0010^{*} \\
(-9.9)\end{array}$ & $\begin{array}{l}-0.0004^{*} \\
(-19.2)\end{array}$ & $\begin{array}{l}0.0003^{*} \\
(2.1)\end{array}$ & $\begin{array}{l}0.0004^{*} \\
(16.4)\end{array}$ \\
\hline Import Exchange Rates & & $\begin{array}{l}0.0005^{\star} \\
(3.9)\end{array}$ & $\begin{array}{l}-0.0000 \\
(-1.5)\end{array}$ & $\begin{array}{l}-0.0004^{*} \\
(-2.5)\end{array}$ & $\begin{array}{l}-0.0001^{*} \\
(-3.7)\end{array}$ \\
\hline Export Orientation & & $\begin{array}{l}0.0111 \\
(0.8)\end{array}$ & $\begin{array}{l}0.0100^{\star \star} \\
(1.78)\end{array}$ & $\begin{array}{l}0.0214 \\
(1.4)\end{array}$ & $\begin{array}{l}0.0006 \\
(0.1)\end{array}$ \\
\hline Import Orientation & & $\begin{array}{l}0.0162^{\star} \\
(2.7)\end{array}$ & $\begin{array}{l}0.0442^{*} \\
(8.0)\end{array}$ & $\begin{array}{l}0.0213^{*} \\
(3.1)\end{array}$ & $\begin{array}{l}0.0495^{\star} \\
(8.4)\end{array}$ \\
\hline$N$ & & 29400 & 286878 & 29400 & 286878 \\
\hline Adjusted $\mathrm{R}^{2}$ & & 0.012 & 0.007 & 0.037 & 0.038 \\
\hline
\end{tabular}

Notes: * Statistically significant at the 0.05 level.

** Statistically significant at the 0.1 level.

Source: Author's calculations at the Center for Economic Studies, US Census Bureau. 
Table 4. Signs and significance of regression coefficients for wage share models for individual high-tech sectors ( $t$-statistics in parentheses)

$$
\text { Dependent }
$$

Non-production Wage Share

\begin{tabular}{|c|c|c|c|c|c|c|c|c|c|c|c|c|c|c|c|c|c|c|}
\hline Explanatory & $\begin{array}{c}\text { SIC } \\
2819\end{array}$ & $\begin{array}{c}\text { SIC } \\
2834\end{array}$ & $\begin{array}{c}\text { SIC } \\
3499\end{array}$ & $\begin{array}{c}\text { SIC } \\
3531\end{array}$ & $\begin{array}{c}\text { SIC } \\
3541\end{array}$ & $\begin{array}{c}\text { SIC } \\
3579\end{array}$ & $\begin{array}{c}\text { SIC } \\
3651\end{array}$ & $\begin{array}{c}\text { SIC } \\
3652\end{array}$ & $\begin{array}{c}\text { SIC } \\
3674\end{array}$ & $\begin{array}{c}\text { SIC } \\
3679\end{array}$ & $\begin{array}{c}\text { SIC } \\
3699\end{array}$ & $\begin{array}{c}\text { SIC } \\
3721\end{array}$ & $\begin{array}{c}\text { SIC } \\
3724\end{array}$ & $\begin{array}{c}\text { SIC } \\
3728\end{array}$ & $\begin{array}{c}\text { SIC } \\
3825\end{array}$ & $\begin{array}{c}\text { SIC } \\
3841\end{array}$ & $\begin{array}{c}\text { SIC } \\
3842\end{array}$ & $\begin{array}{c}\text { SIC } \\
3861\end{array}$ \\
\hline Intercept & - & $+^{\star}$ & + & - & - & - & $t^{*}$ & $+^{*}$ & - & $-*$ & - & + & - & $+{ }^{\star \star}$ & + & + & + & + \\
\hline Capital Intensity & - & + & + & $-\star$ & $-*$ & $+^{*}$ & - & $-\star$ & $+*$ & $+^{*}$ & $+*$ & + & + & - & + & + & + & $+^{*}$ \\
\hline Population Density & - & + & - & + & - & - & $+\star \star$ & + & - & - & - & $+*$ & - & + & + & - & + & $+^{*}$ \\
\hline Manufacturing Share & - & $-\star \star$ & - & - & - & - & $-*$ & $-*$ & + & - & - & $-\star$ & - & - & - & - & $+\star \star$ & $-*$ \\
\hline State Unionization Rate & - & - & + & + & $+^{*}$ & + & - & $-* *$ & + & - & - & $-\star *$ & - & $-*$ & + & + & + & - \\
\hline Total Shipments & $-\star$ & + & $+*$ & - & - & - & - & + & $+*$ & $+*$ & $+*$ & - & + & $+*$ & + & $+^{*}$ & $+^{*}$ & $+^{*}$ \\
\hline Total Employment & $+*$ & + & $-*$ & $+*$ & + & + & $+^{*}$ & + & $-*$ & $-*$ & $-\star \star \star$ & + & - & $-*$ & - & - & $-*$ & $-*$ \\
\hline Export Exchange Rates & $-*$ & $-*$ & $+^{*}$ & $+^{*}$ & $-\star$ & $+^{\star}$ & - & $-*$ & $+*$ & $-*$ & $-*$ & + & - & $+^{*}$ & + & $+^{*}$ & - & $+^{*}$ \\
\hline Import Exchange Rates & $+^{*}$ & $+^{*}$ & $-*$ & - & $+^{*}$ & $-*$ & $-\star \star \star$ & $+^{*}$ & $-*$ & + & $-\star$ & + & + & + & - & $-*$ & $+^{*}$ & + \\
\hline Export Orientation & - & $+^{*}$ & $-*$ & $-\star \star$ & $-*$ & + & $+*$ & $-*$ & + & $+* \star$ & $+^{*}$ & - & $+^{\star}$ & $-*$ & $-*$ & - & $-\star$ & $-*$ \\
\hline Import Orientation & $+*$ & $-*$ & $+*$ & $+*$ & $+^{*}$ & + & $-*$ & $-\star$ & - & $+^{\star}$ & $-\star$ & - & $-*$ & $+^{*}$ & + & $+^{*}$ & $+^{\star}$ & - \\
\hline$N$ & 1168 & 1007 & 2879 & 1656 & 708 & 352 & 683 & 498 & 779 & 2003 & 964 & 286 & 570 & 917 & 898 & 1125 & 1691 & 917 \\
\hline Adjusted $\mathrm{R}^{2}$ & 0.05 & 0.03 & 0.05 & 0.02 & 0.03 & 0.05 & 0.07 & 0.19 & 0.05 & 0.08 & 0.16 & 0.04 & 0.01 & 0.09 & 0.01 & 0.04 & 0.03 & 0.06 \\
\hline
\end{tabular}

Notes: * Statistically significant at the 0.05 level.

** Statistically significant at the 0.1 level.

1 Sector descriptions for SIC Codes found in Table 2.

Source: Author's calculations at the Center for Economic Studies, US Census Bureau. 
Table 5. Signs and significance of regression coefficients for employment share models for individual high-tech sectors ( $t$-statistics in parentheses)

\begin{tabular}{|c|c|c|c|c|c|c|c|c|c|c|c|c|c|c|c|c|c|c|c|}
\hline \multirow[b]{2}{*}{ Explanatory } & \multirow[t]{2}{*}{ Dependent $^{1}$} & \multicolumn{18}{|c|}{ Non-production Employment Share } \\
\hline & & $\begin{array}{c}\text { SIC } \\
2819\end{array}$ & $\begin{array}{c}\text { SIC } \\
2834\end{array}$ & $\begin{array}{c}\text { SIC } \\
3499\end{array}$ & $\begin{array}{c}\text { SIC } \\
3531\end{array}$ & $\begin{array}{c}\text { SIC } \\
3541\end{array}$ & $\begin{array}{c}\text { SIC } \\
3579\end{array}$ & $\begin{array}{c}\text { SIC } \\
3651\end{array}$ & $\begin{array}{c}\text { SIC } \\
3652\end{array}$ & $\begin{array}{c}\text { SIC } \\
3674\end{array}$ & $\begin{array}{c}\text { SIC } \\
3679\end{array}$ & $\begin{array}{c}\text { SIC } \\
3699\end{array}$ & $\begin{array}{c}\text { SIC } \\
3721\end{array}$ & $\begin{array}{c}\text { SIC } \\
3724\end{array}$ & $\begin{array}{c}\text { SIC } \\
3728\end{array}$ & $\begin{array}{c}\text { SIC } \\
3825\end{array}$ & $\begin{array}{c}\text { SIC } \\
3841\end{array}$ & $\begin{array}{c}\text { SIC } \\
3842\end{array}$ & $\begin{array}{c}\text { SIC } \\
3861\end{array}$ \\
\hline Intercept & & - & $t^{*}$ & - & - & + & + & - & $t^{*}$ & - & + & $-*$ & - & + & $+^{\star}$ & - & + & $-\star \star$ & + \\
\hline Capital Intensity & & $-\star \star *$ & - & - & $-*$ & $-\star$ & $+* \star$ & - & - & $+^{*}$ & + & $+^{*}$ & + & + & $-\star \star$ & - & - & - & + \\
\hline Population Density & & + & + & + & + & + & $-\star$ & + & + & + & - & - & $+^{*}$ & + & + & + & $-\star \star *$ & + & $+^{*}$ \\
\hline Manufacturing Share & & - & $-*$ & - & - & - & - & - & $-*$ & - & - & + & $-\star$ & - & - & - & + & + & - \\
\hline State Unionization Rate & & + & $-\star *$ & $+^{*}$ & - & + & $+* *$ & - & - & + & $-* \star$ & - & $-*$ & + & - & + & + & $+* \star$ & + \\
\hline Total Shipments & & $-*$ & - & + & - & $-\star \star$ & - & - & - & + & + & $+*$ & $-*$ & - & - & $-\star *$ & + & - & + \\
\hline Total Employment & & $+^{*}$ & + & $+^{*}$ & $+^{*}$ & $+^{*}$ & + & $+*$ & $+*$ & - & + & + & $t^{*}$ & $t^{*}$ & $+*$ & $+^{*}$ & $+*$ & $+^{*}$ & $+^{*}$ \\
\hline Export Exchange Rates & & - & $-*$ & $-*$ & $+^{*}$ & + & + & $+^{*}$ & $-*$ & $+^{*}$ & $+^{*}$ & - & + & - & $+^{*}$ & $+^{*}$ & $+^{*}$ & $-*$ & $+^{*}$ \\
\hline Import Exchange Rates & & + & $+*$ & $+*$ & $-*$ & - & $-*$ & $-*$ & $+*$ & $-*$ & $-*$ & $-*$ & + & $+* \star$ & - & $-*$ & $-*$ & $+*$ & $-*$ \\
\hline Export Orientation & & + & $+*$ & - & $-*$ & + & $+*$ & + & $-\star$ & - & $+^{*}$ & + & - & $+*$ & $-*$ & $-*$ & $-*$ & $-*$ & $-*$ \\
\hline Import Orientation & & $+^{*}$ & $-*$ & $-*$ & $+^{*}$ & + & - & $+^{*}$ & -* & - & $+^{*}$ & - & - & -* & + & $+^{*}$ & $+^{*}$ & $+^{*}$ & + \\
\hline$N$ & & 1168 & 1007 & 2879 & 1656 & 708 & 352 & 683 & 498 & 779 & 2003 & 964 & 286 & 570 & 917 & 898 & 1125 & 1691 & 917 \\
\hline Adjusted $\mathrm{R}^{2}$ & & 0.08 & 0.05 & 0.11 & 0.09 & 0.04 & 0.13 & 0.15 & 0.13 & 0.14 & 0.05 & 0.16 & 0.08 & 0.04 & 0.11 & 0.09 & 0.08 & 0.05 & 0.1 \\
\hline
\end{tabular}

Notes: * Statistically significant at the 0.05 level.

** Statistically significant at the 0.1 level.

1 Sector descriptions for SIC Codes found in Table 2.

Source: Author's calculations at the Center for Economic Studies, US Census Bureau. 
Figure 1. Traditional and Hi-Tech Manufacturing Earnings by County, 1972
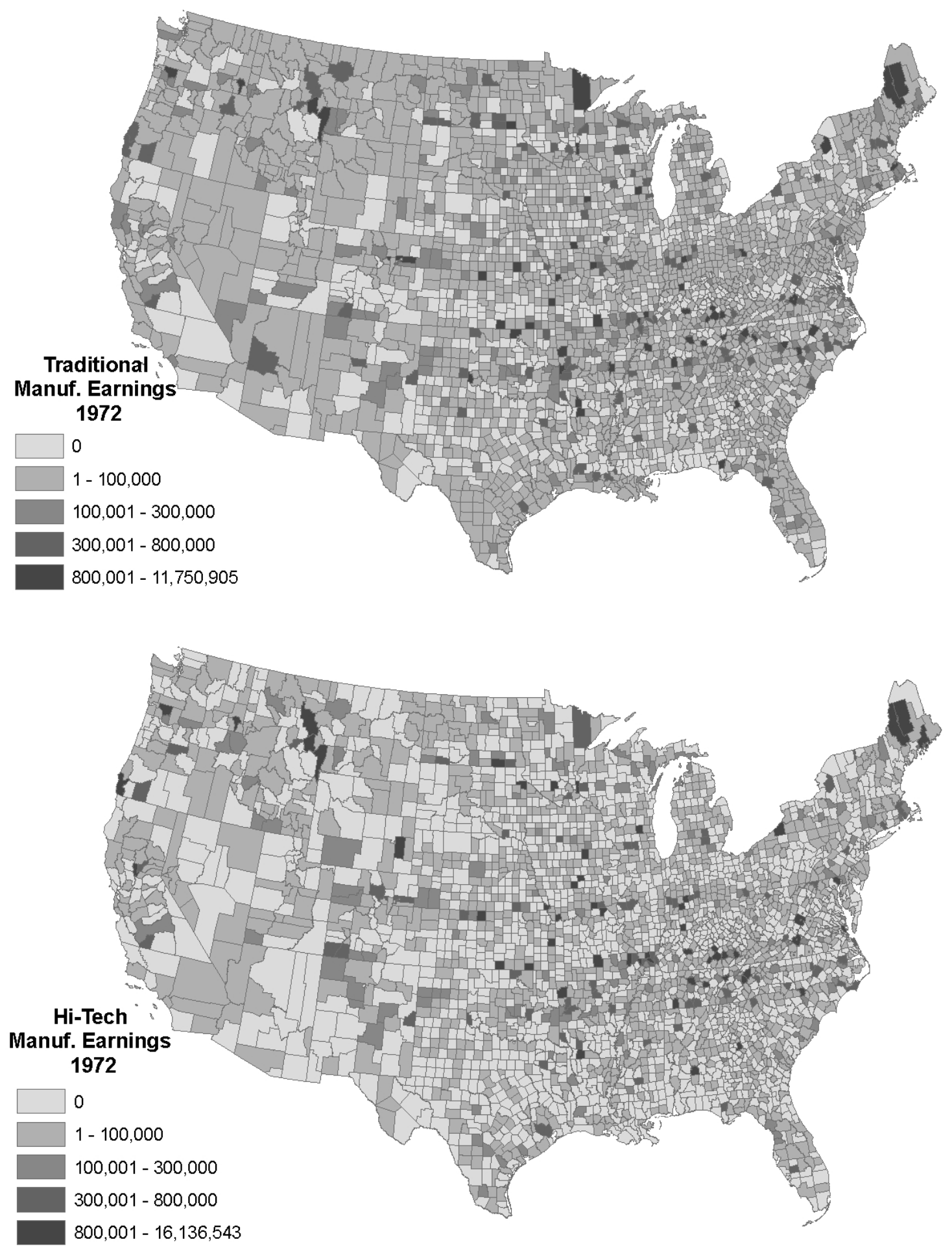

Source: US Census, 2001; author's calculations 
Figure 2. Traditional and Hi-Tech Manufacturing Percentage Change in Earnings by

County, 1972-1997
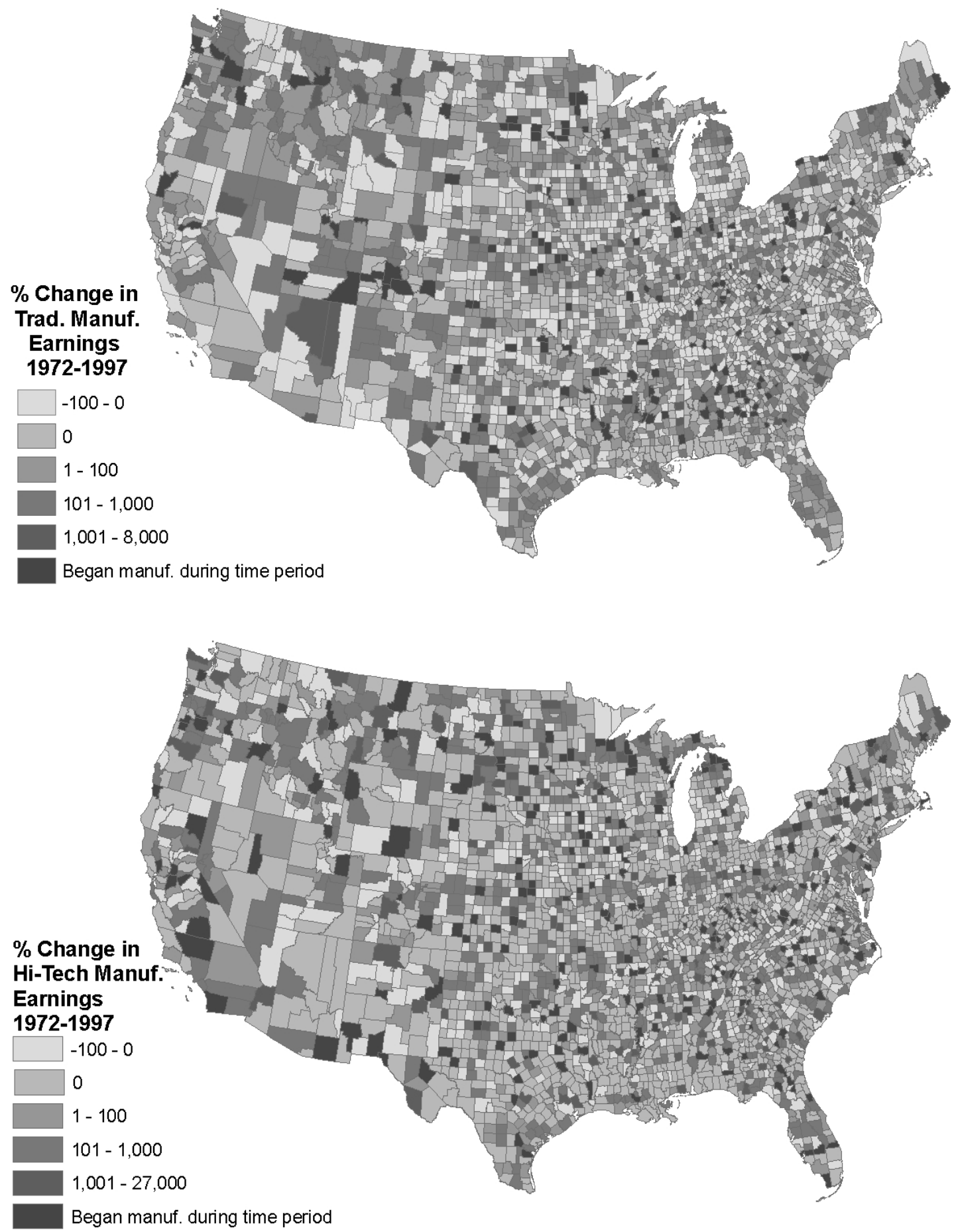

Source: US Census, 2001; author's calculations 